\title{
THE ROLE OF STRATEGIC REASONING IN CONSTITUTIONAL INTERPRETATION: IN DEFENSE OF THE PATHOLOGICAL PERSPECTIVE
}

\author{
VINCENT BLASI*
}

I am indebted to Professor Christie, not only for noticing my work but also for challenging it in so forthright a inanner. He has identified a feature of my thesis that deserves to be a focal point for additional debate. Any reader of my original article who was undecided whether to agree with it ought to be aided considerably in the task of critical evaluation by the exchange Professor Christie has initiated. I know my own understanding of the premises and implications of my thesis has been enhanced by the experience of working out a response to his challenge.

The crux of Professor Christie's critique is contained in the following passages: "The notion I find most troublesome in Blasi's argument is that, in deciding individual cases, courts must constantly keep in mind strategic considerations." 1 "I find it a disturbing suggestion that a person's legal claim should stand or fall, not on the strength of his argument, but on some strategic view taken by the Court or on the background views of soine member of the Court regarding what is good for society."2 I take his claim to be that strategic considerations have no place in the process of constitutional interpretation, or at least that the particular strategic considerations that I think should be taken into account have no proper place. He views the use I make of strategic considerations as inconsistent with "the ideal of the rule of law."3

I believe strategic thinking has a linited but vital role to play in the developinent of a constitutional tradition. I do not believe that a properly limited conceru for strategic considerations is inconsistent with the ideal of the rule of law; indeed, I think such a concern for strategy serves the rule of law. I agree with Professor Christie that constitutional inter-

* Corliss Lamont Professor of Civil Liberties, Columbia Law School. B.A., 1964, Northwestern University; J.D., 1967, University of Chicago.

1. Christie, Why the First Amendment Should Not Be Interpreted From the Pathological Perspective: A Response to Professor Blasi, 1986 Duke L.J. 683, 689 [hereinafter Christic, Response].

2. Id. at 690 .

3. Id. at 695 . 
pretation, at least when undertaken by the judiciary, must have the quality of law. I agree also that constitutional adjudication would lose the quality of law were it to become in essence "the same thing as politics" or "the same thing as the search for moral perfection." 4 The question that divides us most slarply is whether the type of strategic thinking I advocate, which seems to ine quite selective and quite structured, is likely to corrupt judicial reasoning to the point where the distinction between law and politics or law and the search for moral perfection is lost.

My starting point is the view that "[t]he first task of any system of constitutional limitations is to guarantee that the truly fundamental features of the framework of government are maintamed."s I note how this very general function of constitutionalism can be broken down into numerous distinct objectives ${ }^{6}$ that vary widely in theoretical import but sliare an important practical feature: "Whether constitutional provisions are invoked to protect political minorities, break political deadlocks, raise the level of public debate to a nore idealistic plane, or serve any of the other possible objectives of constitutionahism, the relative continuity and stability of the constitutional tradition is likely to have a major impact on the success of the endeavor."7 That observation concernimg functional effectiveness is based on a series of strategic calculations:

Only relatively stable principles are likely to be perceived by divergent political factions as potentially working to their advantage in the long run. Only relatively stable principles are likely to be viewed as worthy of a certain respect simply on account of their capacity to endure. Only if the expositors of constitutional principles avoid being dominated by the political alignments and passions of the present can those whose preferences are backed by force of arms or popular approval be expected to take a long-tern view about the nature of political obligation. $^{8}$

Professor Christie shares my preference for stability and continuity, ${ }^{9}$ but apparently not my derivation of that preference from strategic judgments. Presumably, he values stability and continuity because he finds those qualities constitutive elements of law or essential preconditions for

4. Id. at 690 .

5. Blasi, The Pathological Perspective and the First Amendment, 85 CoLUM. L. Rev. 449, 45253 (1985).

6. See id. at 453.

7. Id. at 454 .

8. Id.

9. Although he does not endorse stability and continuity in so many words, I regard his overriding concern for "objectivity" and "consistency," see Christie, Response, supra note 1, at 694, to carry an implicit endorsement of stability and continuity. In the article on which he explicitly builds the present critique, Professor Christie accords a central place in his analysis to the search for "the fixed reference points of legal reasoning." See Christie, Objectivity in the Law, 78 YALE L.J. 1311, 1326 (1969) [hereinafter Christie, Objectivity]. 
the effective participation of the parties in the adjudicative process. ${ }^{10}$ If these speculations on my part are incorrect or incomplete, and if, for example, he values stability and continuity of doctrine in part because those qualities help to constrain the antidemocratic and potentially dangerous power of judges, then he would be guilty of the saine type of strategic reasoning that informs my preference for stability and continuity.

Having decided, on strategic grounds, that stability and continuity are important qualities of a constitutional tradition, I proceed to distinguish the core commitinents of such a tradition from the surrounding elements and to search for methodologies and doctrines that maximize the prospect that those core commitments will remain vital through the vicissitudes of political experience. Again, the effort to identify such a core is inspired by a strategic judgment: given the irresistible and often salutary pressures toward dynamism in the development of a constitutional tradition, the cause of stability is served if certain value propositions that are part of that tradition are separated from the rest and viewed as relatively (though not totally) immune froin reinterpretation or abandoninent.

I should emphasize that although my einbrace of the concept of core commitments stems in part from strategic considerations, my specification of precisely what propositions constitute the core of the first amendment (or of any other constitutional provision) does not derive, even in part, from any sort of strategic calculation. My test of pedigree for inclusion in the core is actual acceptance over time by the legal and political culture. ${ }^{11}$ That is the antithesis of a test based on conformity with a particular political philosophy, or search for moral perfection, or instrumental judgment regarding how one or more primary values inight be served. Because of my positivistic conception of the core, the value cominitments I take to constitute the core of the first amendment "tend to be simple, discrete, situation-oriented, and accessible."12 Most of them are "relatively specific in nature."13 If this stage of my proposed inethod of constitutional reasoning does not have the quality of law, it is not due to the corrupting influence of strategic calculation or perfectionist moral philosophizing.

Professor Christie, however, appears to find in my specification of the core of the first amendment a good deal more picking and choosing than can be countenanced by the foregoing account. He notes that I do not include certain doctrines, the protection of commercial advertising

10. See Christie, Objectivity, supra note 9 , at 1329-30.

11. See Blasi, supra note 5, at 459-62.

12. Id. at 460.

13. Id. 
for example, that have been adopted in recent years by the Supreme Court. ${ }^{14}$ He claims that I have abandoned "the historical perspective," given too much emphasis to pohtical speech, and included too many propositions that are "of very late genesis." 15 The result, he believes, is that the core of the first amendment that forms the cornerstone of my theory of constitutional interpretation exists only "in the eyes of the beholder." 16

That is a charge I take very seriously, because if he is right my thesis cannot be defended. Of course, were Professor Christie to convince me not that the concept of the core is untenable but only that I have misjudged what ought to be included in the core, the thesis would not be discredited. I would simply have to revise my view of what doctrinal implications follow from adoption of the pathological perspective in light of the new understanding of the content of the core. (I doubt whether my views regarding methodological implications would have to be altered.)

I do not share Professor Christie's view that the core propositions I invoke are mostly of very late genesis. In the portion of my article that he quotes on this point, I cite several cases in support of each of the core propositions I identify. I cite several cases for each proposition because I believe acceptance over time by the legal culture is a prerequisite for recognition as a core commitment. The process of validation I have in mind ordinarily entails acceptance in a variety of settings and a pattern of steady development by which the core proposition comes to figure increasingly as a reference point for reasoning about first amendment problems. Thus, some of the cases I cite are recent. But each core proposition I identify also finds support in cases that are not so recent. The dates of the earliest cases cited for the eleven core propositions I identify are respectively: 1931, 1957,1949, 1939, 1943, 1957, 1961, 1931, 1959, 1925 , and $1927 .{ }^{17}$ I do not claim that the core propositions I have identified were fully crystallized by those dates. Nor do I deny that subsequent recognition and development was essential to the einergence of those core propositions as central features of the first amendment tradition. My point is that the core propositions that I discern in the first amendment tradition are not of "very late genesis," and do not represent simply a selective list of iny favorite contemporary doctrines and principles. I clain to have derived the core of the first amendment from a reading of history.

14. Christie, Response, supra note 1 , at 687-88.

15. Id.

16. Id. at 688.

17. See Blasi, supra note 5 , at 460-61 \& nn.15-25. 
Professor Christie is unsympathetic to this claim partly because he believes that one who adopts a "listorical perspective" must emphasize original history, in the sense of the intentions of the framers of the first amendment, rather than the intervening, ongoing history of adjudication and professional commentary. ${ }^{18} \mathrm{He}$ then finds merit in a reading of the framers' intentions that makes the first ainendinent into a provision more about federalisin than liberty, and concludes that this original history does not support iny contention that the core of the first amendment consists of a configuration of propositions about liberty of expression and belief. ${ }^{19}$

I think he is wrong, even granting his premise that original history is the history that matters the most. Recent scholarship has cast much doubt on the familiar thesis of Professor Levy that the framers of the first amendment had a narrow, legalistic, Blackstonian understanding of the meaning of freedom of speech. ${ }^{20}$ Of course, it is entirely possible, as Professor Van Alstyne has suggested, ${ }^{21}$ that many of the framers had a grand view of the freedom of speech but expected the first amendment to constrain only the federal government, trusting to state constitutions to preserve that essential liberty against infringement by state and local governments. If so, one who advocates a narrow reading of the federal constitution's protection for freedom of speech on grounds of original history must show that the intentions of the frainers of the fourteenth amendment were also narrow, that a robust right to freedom of speech was not one of the privileges and immunities of citizens or one of the guarantees of due process protected against state encroachinent by that amendment.

I take issue with Professor Christie's reading of original history, but I do so gingerly because I have no confidence in anyone's-my own, Professor Christie's, Professor Levy's, Justice Black's-capacity to reconstruct what the framers intended. To my mind, the critiques of that interpretive inethodology offered in recent years by Professors Brest,

18. See Christie, Response, supra note 1, at 687-88.

19. See id.

20. See Anderson, The Origins of the Press Clause, 30 UCLA L. REv. 455 (1983); Mayton, Seditious Libel and the Lost Guarantee of a Freedom of Expression, 84 CoLUM. L. Rev. 91 (1984); Rabban, The Ahistorical Historian: Leonard Levy on Freedom of Expression in Early American History, 37 STAN. L. Rev. 795 (1985). Professor Levy's thesis is set out in L. Levy, EMERGENCE of A Free Press (1985), a revision of L. LEVY, LEGACY OF SUPPRESSION: FREEDOM OF SPEECH AND Press in EARLy American History (1960). Professor Levy has responded to Professor Anderson in Levy, On the Origins of the Free Press Clause, 32 UCLA L. REv. 177 (1984), and to Professor Mayton in Levy, The Legacy Reexamined, 37 STAN. L. REv. 767 (1985).

21. See Van Alstyne, Congressional Power and Free Speech: Levy's Legacy Revisited (Book Review), 99 HaRv. L. REv. 1089, 1097 (1986). 
Dworkin, and Sandalow are unanswerable. ${ }^{22}$

Perhaps Professor Christie would answer me in kind. He might take issue with my reading of the intervening history of adjudication and public debate regarding the meaning of the first alnendment. He might coinpile a different list of core propositions, citing different case holdings, different flights of rhetoric froin different judges, different scholarly coininentaries, and different assumptions articulated in public debate. I do not deny that the evolving tradition of the first amendinent can be read in various ways: "[T] give ineaning to any text or event we cannot help but draw upon our own values, perceptions, and focal mechanisins."23 But I would argue that fair-minded interpretors of interverning history are likely to agree more than fair-minded interpretors of original history because the first group of interpretors are working with materials to which they have a closer and inore vital connection. We hive and work at the tail end of the line of growth that constitutes our first ainendinent tradition. The effort to trace that line of growth is a more meaningful endeavor than is the effort to reconstruct a snapshot of one moment in the reinote past.

I ain particularly confident that the process of interpreting intervening history can have integrity when the inquiry concerns not the furthest reaches of the tradition but the core. I cannot imagine, for example, that any fair-ininded interpretor of the first ainendinent tradition would dismiss or ignore the Holmes opmion in Abrams v. United States, ${ }^{24}$ the Brandeis opinion in Whitney v. California, ${ }^{25}$ or the inajority opmions in Near v. Minnesota, ${ }^{26}$ Bridges v. California, ${ }^{27}$ and New York Times v. Sullivan. ${ }^{28}$ Fair-minded interpretors no doubt would disagree about whether cases such as Thornhill v. Alabama ${ }^{29}$ or Dennis v. United States $^{30}$ reinam a vital part of the first amendinent tradition, or whether Buckley v. Valeo ${ }^{31}$ or Virginia Board of Pharmacy v. Virginia Citizens Consumer Council ${ }^{32}$ have yet proven their capacity to endure. In the

22. See Brest, The Misconceived Quest for the Original Understanding, 60 B.U.L. REv. 204 (1980); Dworkin, The Forum of Principle, 56 N.Y.U. L. REv. 469 (1981), reprinted in R. DwORKIN, A Matter of Principle 33 (1985); Sandalow, Constitutional Interpretation, 79 Mich. L. Rev. 1033 (1981).

23. Blasi, supra note 5 , at $454-55$.

24. 250 U.S. 616, 624 (1919) (Holmes, J., dissenting).

25. 274 U.S. 357,372 (1927) (Brandeis, J., concurring).

26. 283 U.S. 697 (1931).

27. 314 U.S. 252 (1941).

28. 376 U.S. 254 (1964).

29. 310 U.S. 88 (1940) (labor picketing).

30. 341 U.S. 494 (1951) (conspiracy by close-knit group to advocate revolution).

31. 424 U.S. 1 (1976) (per curiam) (campaign financing).

32. 425 U.S. 748 (1976) (commercial advertising). 
highly charged area of obscenity, I think fair-minded interpretors would agree that the closest thing to a core proposition recognized by the first amendment tradition is the rejection of thematic obscenity (the regulation of sexual ideas, such as the propriety of adultery, as contrasted with sexual imagery), first accomplished in Kingsley Pictures v. Board of Regents ${ }^{33}$ and treated as a standard reference point ever since. I cannot imagine a group of fair-minded imterpretors agreeing on what to make of the welter of cases since Roth v. United States ${ }^{34}$ dealing with patent offensiveness, redeeming social value, child pornography, and claims to enjoy pornographic materials in private. ${ }^{35}$ At the periphery, the first amendment tradition, like any other tradition, is so indeterminate that one has to beheve interpretors of the tradition draw heavily on their personal preferences or philosophies in rendering their interpretations. At the core of the tradition, in contrast, the personal element in the process of interpretation need not dominate the enterprise.

Professor Christie does not regard as central to his critique his challenge to iny claim that the core propositions of the first amendment tradition can be identified by an interpretive process, looking to intervening rather than original history, that has integrity. Ironically, I think his challenge is more threatening to iny thesis than he does, because I agree with him that constitutional interpretation should not be dominated by either strategic calculation or personal philosophizing. I am at pains to prove that strategic reasoning plays only a carefully confined role in my proposed inethod of constitutional interpretation. The derivation of the core is one of the inportant stages of constitutional analysis at which I think judges should eschew all strategic calculation.

In contrast, the strategic point of view should, I believe, inform the choice of interpretive inethodologies for ruling upon the vast array of first ainendment claims that courts are required to decide. In order best to preserve and nurture the core propositions of the first amendment, I urge courts to emphasize and glorify historical benchmarks, ${ }^{36}$ to invoke simple precepts regarding expressive liberty, ${ }^{37}$ to integrate coinplex strands of analysis imto relatively concise principles, ${ }^{38}$ to avoid indiscriminate innovation, ${ }^{39}$ to keep the anbit of first amendment concern within

33. 360 U.S. $684,688-89$ (1959).

34. 354 U.S. 476 (1957).

35. See, eg., W. LockHART, Y. KAMisaR, J. CHOPER \& S. SHIFFrin, CONSTITUTIONAL LAW: CASES, CoMments, QUesTIONs 709-40 (6th ed. 1986).

36. Blasi, supra note 5 , at 469 .

37. Id. at 472. One colleague refers to this proposal as my "mantra" theory of the first amendment.

38. Id. at $473-74$.

39. Id. at 476 . 
bounds that comport with popular understanding, ${ }^{40}$ and to construct doctrines that can take account of certain destabilizing social phenoinena. ${ }^{41}$ One could, of course, accept or reject any of these metliodological recoininendations on some basis other than strategic efficacy, but my reason for preferring them is unashamedly strategic.

Here, I gather, is where Professor Christie is especially out of sympathy with my thesis. He favors a method of constitutional interpretation tliat is based on "proofs and arguments put forward by the parties"; 42 he views this einphasis on the parties as central to the "model of consistency" he developed in his well-known 1969 article. ${ }^{43}$ Were courts to favor the metlodologies I recommend as a strategy to combat pathologies, the result would be just another example of judicial reasoning "on the basis of soine preconceived idea of what is good for the country, or the world, or the universe, or on the basis of some prudential strategy of judicial decisionmaking." $44 \mathrm{He}$ states his cardinal tenet succinctly: "[T]he correct decision m any particular case must be one that is primarily determined by the dynamics of the legal argnment in that particular case ratlier than by a theory of the good encompassing the whole of society." 45

I am not certain exactly what Professor Christie means by "proofs and arguments put forward by the parties" and a judicial decision "primarily determined by the dynamics of the legal argument in that particular case." Under the inethod of constitutional interpretation that I propose, parties certainly would make proofs and arguments regarding whether their clamis fall within or without the precepts and principles of the first amendinent tradition. The parties would argue about whether the classic benchmarks of the tradition are analogous to the case before the court. I envision situation-specific arguments over such phenoinena as the chilling effect. In fact, several of the methodological priorities tliat are indicated by the pathological perspective-the enphasis on historical benchınarks, the careful attention given to formulating principles, the cautious approacli to doctrinal innovation-ought to enhance the role of the parties to a lawsuit by giving them reference points for argumentation that are more accessible and nore stable thian the reference points provided by our current constitutional jurisprudence. I would understand Professor Christie's objection had I proposed a method of constitu-
40. Id. at $478-79$.
41. Id. at $482-84$.
42. Christie, Response, supra note 1, at 694.
43. Christie, Objectivity, supra note 9, at 1333-41.
44. Christie, Response, supra note 1, at 694.
45. Id. 
tional interpretation in which judges decided cases by first imagining that they occurred amidst a social pathology of repression and then rendering ad hoc judgments based not on previously established legal doctrines but rather prudential assessments of how best to combat the hypothesized pathology. But that is a far cry from the method I spelled out in my article.

Thus, I am curious what types of "proofs and arguments" would figure in Professor Christie's model of consistency that do not figure in my preferred method of constitutional interpretation. From his 1969 article it appears he would make more use of the analytical device of paradigm cases than do most contemporary judges. ${ }^{46}$ So would I, at least regardimg the core propositions of the first amendment tradition. It is clear both from the 1969 article and the current response that Professor Christie wishes to reduce the roles of personal judicial preference and perfectiomst moral theory in the process of constitutional interpretation. ${ }^{47}$ So do I. In my article I search for ways to avoid the type of doctrinal complexity that is exemplified by "a multi-factor balancing test, a multi-stage analysis with a threshold level-of-scrutiny determination, or a standard that is highly dependent on particularistic assessments of motive, risk, and efficiency."48 As I understand his model of consistency, Professor Christie ought also to be troubled by a system that requires the parties to fashion their "proofs and arguments" in such a morass of doctrinal complexity. On the surface, there would seem to be a good deal of overlap in the methodological and doctrinal implications of our respective approaches to constitutional adjudication.

I can only conclude that the real difference between us is that I derive my methodological and doctrinal preferences from strategic calculation informed by the pathological perspective and he derives his preferences-for the use of paradigm cases, for example, or for a high level of constitutional protection for commercial advertising-from a nonstrategic mode of reasoning. This difference could be important for either of two reasons. First, Professor Christie may believe it is simply wrong in principle for courts to employ strategic reasoning at any stage of the process of formulating constitutional doctrine. Second, he may believe that if strategic reasoning is legitimated at the stage when methodological and doctrinal priorities are determined, courts will inevitably lapse into a strategic mode of thought when it comes time to apply the strategically derived methodologies and doctrines to particular disputes.

46. See Christie, Objectivity, supra note 9, at 1333-41.

47. See id. at 1330-31; Christie, Response, supra note 1, at 690, 692.

48. Blasi, supra note 5 , at 473 . 
On the first point, I must confess to a certain skepticism regarding whether it is even possible to expunge strategic considerations from all stages of constitutional analysis. As suggested above, I would be surprised if Professor Christie's preference for stability and continuity of doctrine were not derived in part from a strategic calculation about how best to constrain the power of judges. I would be surprised if his insistence that judges always respond explicitly to all contentions put forth by the parties ${ }^{49}$ were not derived in part from the strategic calculation that judges so obligated are less likely to engage in the type of doctrinal innovation he dislikes. I would be surprised if his behef that racial preferences are unconstitutional per se, without regard to which race is disadvantaged and what motivations inform the use of racial criteria, ${ }^{50}$ were not derived in part from the strategic calculation that the paramount task of reducing discrimination against minority races is hikely to be best served if whites see the constitutional principle regarding the use of racial criteria as sometimes working to their advantage as well; perceived asymmetry in a legal doctrine can erode respect for law even when good reasons exist for the asymmetry. ${ }^{51} \mathrm{I}$ admit that as a inatter of logic one could derive these methodological and doctrinal preferences from nonprudential, nonstrategic considerations, but I liave my doubts whether as a matter of actual practice one is likely to eschew strategic reasoning at this stage of the legal reasoming process.

In any event, I do not coinprehend what is improper in principle about strategic reasoning when confined as I have tried to confine it. The term "strategic" may conjure up images of clandestine game plans or adversarial plotting or militaristic ruthlessness, but what it means in essence to have a strategy is to consider exphcitly and/or systematically how best to achieve one's objectives. As Professor Christie recognizes, the term carries connotations of prudence and pragmatic judgment, and surely those quahities have a respected place in legal reasoning. Of course, strategy is always in the service of seeking to achieve objectives, and thus a strategic point of view presupposes an instrumental, goal-oriented point of view. And I admit that instrumentalism can play too large a role in legal reasoning, and probably has in the postwar period. But I liave paid a good deal of attention to the task of marking out only a limited ambit for strategic reasoning. In the method of constitutional interpretation I advocate, strategic reasoning has no role to play in deter-

49. See Christie, Objectivity, supra note 9, at 1329-30; Christie, Response, supra note 1, at 69394.

50. Christie, Response, supra note 1 , at 692.

51. For a detailed account of why I believe good reasons exist for the asymmetry, see Blasi, Bakke as Precedent: Does Mr. Justice Powell Have a Theory? 67 CALIF. L. REv. 21, 36-61 (1979). 
mining what propositions constitute the core of the first amendment. Nor do I encourage judges to invoke strategic considerations when applying to particular fact situations whatever methodologies and doctrines are thought best to serve the primary objective of safeguarding and strengthening the core of the first amendment.

In short, the limited use I make of the strategic point of view seeins fully consonant with the ideal of the rule of law. The priority I accord the objective of safeguarding core constitutional commitments may be disputable on theoretical grounds, but if that priority is defensible in terms of the theory of constitutionalism, I do not believe my effort to implement the priority in a strategically effective manner violates any significant norms or traditions of legal reasoming.

There remains a practical objection implicit in Professor Christie's critique, and I cannot help but beheve that his deepest concern with my thesis relates to this practical point. Although I advocate that judges keep strategic reasoning to a minimum when applying established doctrimes and methodologies to particular cases, is there not a serious risk that the strategic mentahity will spill over to and corrupt such judgments of application? If that were to happen, the claims of law and equity pecuhar to the parties before the court could be dwarfed by systemic concerns. And there is force to the contention that the quality of law may be lacking in a system of adjudication that treats litigants not as distinctive bearers of legal rights and obligations but rather as adventitious objects of judicial decisionmaking directed to long-range, large-scale ends.

This is not to suggest that a proper respect for individual litigants requires that courts decide constitutional disputes on an ad hoc basis without reference to past commitments or future consequences. The parties to litigation are not entitled to have their persons or experiences sensitively examined by courts: the parties are entitled to have their legal claims sensitively examined. Those claims are based on expectations regarding how legal norms of a general character apply to particular fact situations. One can attempt, as Professor Christie does in his 1969 article, to formulate the norms in the inost concrete idiom possible-hence his preference for paradigm cases ${ }^{52}$ - but such a move does not eliminate the need to resolve disputes with reference to considerations of a general character. For even if the mode of reasoning is predominantly analogical rather than inductive or deductive, one cannot pass judgment on a clained analogy witlout having soine reasons for treating certain factual similarities and differences as relevant and others as irrelevant.

52. See Christie, Objectivity, supra note 9, at 1334-36. 
I do not understand Professor Christie to urge that disputes between constitutional litigants be resolved solely on the basis of considerations specific to the particular lawsuit with no reference to sources of authority or consequences of wider scope. His own discussion of cases belies such an interpretation. For example, he criticizes the Supreme Court for ascribing legal significance in a defanation action to the fact that the defendant wrote about the plaintiff to only a very limited audience and only on a subject of private concern. ${ }^{53} \mathrm{He}$ criticizes the Court for ascribing legal significance in a dispute over commercial advertising to the fact that the activity subject to the advertising prohibition was of such a nature that the government had the authority to outlaw it entirely. ${ }^{54}$ The Court thought those factual features of the cases justified treating earhier decisions protecting defamers and advertisers as not controlling. My own inclination is to agree with the Court rather than Professor Christie regarding the constitutional significance of the facts in question. ${ }^{55}$ That particular inclination is not important, however. What is important is that neither of us could persuade the other on this point without invoking general considerations relating to the underlying reasons for interpreting the first amendment to protect defamatory and commercial speech. He no doubt would want to invoke different kinds of general considerations than I would, but both of us would have to look well beyond the parties in order to accept or reject the distinctions on which they based their claims.

So it is not a telling point to observe that under my proposed method of constitutional interpretation a party wonld soinetimes lose a case it would otherwise win were it not for the general considerations introduced by the concern about future pathological pressures. The objection inust be more narrowly focused. I take it that Professor Christie's criticism concerns matters of degree rather than kind: because of the legitimation of strategic thinking at other stages of the legal reasoming process, he apparently is worried that in applying the methodologies and

53. See Christie, Response, supra note 1, at 693 (discussing Dun \& Bradstreet, Inc. v. Greenmoss Builders, Inc., 105 S. Ct. 2939 (1985)).

54. See id. (discussing Posadas de Puerto Rico Assocs. v. Tourism Co. of Puerto Rico, $106 \mathrm{~S}$. Ct. 2968 (1986)).

55. This is not to say that I necessarily disagree with the views Professor Christie expresses regarding which parties shonld have prevailed in those cases. I am inclined to believe that Dun \& Bradstreet was properly decided, although I am deeply troubled by Justice White's concurring opinion, in which he criticizes the doctrine of New York Times v. Sullivan, 376 U.S. 254 (1964). Dun \& Bradstreet, 105 S. Ct. at 2948-54 (White, J., concurring). I am inclined to think the Court reached the wrong result in Posadas, though for the reasons expressed in Justice Stevens's dissent, see Posadas, $106 \mathrm{~S}$. Ct. at 2986-88 (Stevens, J., dissenting), not because the majority gave weight to the fact that the subject of the advertising ban was casino gambling as distinguished from legal services, prescription drugs, or real estate. 
doctrines imdicated by the pathological perspective courts may give too much weight to general considerations, some of them rather speculative, and not enough weight to the considerations of fairness and justice that pertain peculiarly to the parties before the court.

This is a perfectly legitimate concern, though one that is difficult to evaluate because it depends on a prediction regarding degrees of emphasis in future judicial decisionmaking. It bears repeating that $I$ envision a pattern of adjudication in which judges focus on the claims of individual hitigants regarding how the methodologies and doctrines formulated by the judiciary in light of the pathological perspective apply to their specific situations. For exainple, the pathological perspective lends support to a strong doctrine against prior restraint, and indicates that in deciding what regulations of speech quahify as prior restraints courts should give great weight to the factor of how rapidly, widely, and free from political scrutiny the regulation can be employed. ${ }^{56}$ Once a doctrine and definition of prior restraint is developed, partly on the basis of strategic considerations, is there any reason to believe that in a close case judges will be especially prone to let broad considerations of long-term strategy determine wliether a particular regulation should be classified as a prior restraint? I would liope not. I would want the dominant considerations in such a dispute to be how the particular regulation in question matches up to the general definition of prior restraint developed in previous cases, and liow the regulation compares to previous regulations that have been held to be prior restraints.

Of course, no close question concerining the application of a legal standard can be resolved mechanically or seinantically. If the underlying rationale for a doctrine is partly strategic, soine consideration of strategy is likely to play a role im those judgments of application at the margin that give shape to the doctrine itself. But this phenomenon is bound to operate under any inethod of constitutional interpretation: underlying rationales for doctrines, based on general considerations of theory or policy or systemic colierence, will figure to a degree in all close questions of application. So long as courts give careful attention to the "proofs and arguments put forward by the parties" regarding liow those general considerations bear on tlie particular question of application, we do not view the concerns of the parties as improperly subordinated. I see no special reason to regard tlie parties' concerns as improperly subordinated when the general considerations that underlie a given doctrine relate to the strategy for combatting anticipated patliologies. 
Perhaps there is a peculiar psychology to strategic reasoning that does not operate for other modes of analysis that take general considerations into account. Perhaps such a psychology could lead courts that engage in strategic thought to fail to see the parties before them or to abuse their power in other ways. That is possible, but I await the elaboration and validation of such a psychological hypothesis by one who shares Professor Christie's aversion to the strategic point of view. Until then, I inaintain the position that strategic reasoning has an honorable place in the process of constitutional interpretation. 